\title{
IbM USAHA MIKRO GULA MERAH TEBU DI DESA MANGUNREJO KECAMATAN NGADILUWIH DAN DESA CENDONO KECAMATAN KANDAT KABUPATEN KEDIRI
}

\author{
Nining Purnamaningsih 1 ) Djunaidi 2 )
}

\author{
${ }_{1}$ Fakultas Ekonomi Universitas Kadiri \\ Niningpurnamingsih@gmail.com) \\ ${ }_{2}$ Fakultas Ekonomi Universitas Kadiri \\ Djunaidi@unik-kediri.ac.id)
}

\begin{abstract}
Gula merupakan komoditas penting yang harus disediakan oleh Pemerintah dalam jumlah yang cukup dan dengan harga yang dapat diakses oleh masyarakat. Produksi gula di dalam negeri saat ini tidak sampai 3 juta ton per tahun dan produksi gula setiap tahunnya tidak mengalami pertumbuhan berarti. Sementara di sisi lain konsumsi gula di Indonesia setiap tahunnya meningkat, jumlah konsumsi gula masyarakat Indonesia per tahun sebesar 14,5 juta per kapita per tahun.

Karena meningkatnya jumlah penduduk dalam konsumsi gula, negara berkembang membutuhkan peningkatan konsumsi gula sebanyak 1,5 kali untuk memenuhi kebutuhan gula. Gula di Indonesia terbagi menjadi dua konsumsi langsung (rumah tangga) dan konsumsi tidak langsung (makanan, minuman). Kebutuhan gula untuk konsumsi masyarakat langsung yang dipenuhi dengan gula kristal putih (GKP), dan konsumsi tidak langsung (industri) dipenuhi dengan gula kristal halus (GKR).

Kedua mitra pengabdian masyarakat adalah pabrik berbasis rumah yang membuat gula tebu (gula bathok atau gula bubuk). Dalam melakukan produksi kedua mitra tersebut sudah menggunakan beberapa alat dan mesin, namun alat yang digunakan masih dilakukan secara manual dengan menggunakan tenaga manusia sedangkan mesin yang ada digunakan hanya untuk meremas tebu.

Kegiatan pengabdian masyarakat yang dilakukan adalah melakukan pemasaran produk pelatihan, pelatihan akuntansi keuangan dan penggunaan alat kristal gula. Untuk menghasilkan produktivitas dan diversifikasi produk kedua mitra dibantu dengan Dinamo listrik untuk menggiling tebu dan crane.

Produk yang dihasilkan dari kedua mitra tersebut umumnya hanya dijual melalui pengepul yang mengambil gula tebu setiap hari, sementara kedua mitra ini berpotensi menciptakan produk label sendiri dan bisa dijual langsung ke masyarakat tanpa melewati kolektor, sehingga harganya bisa ditentukan oleh keduanya. mitra sendiri

Kata kunci: tebu, gula tebu, industri mikro
\end{abstract}




\section{PENDAHULUAN}

Indonesia yang merupakan salah satu produsen gula yang memiliki potensi menjadi produsen gula terbesar di dunia. Gula merupakan komuditas penting yang wajib disediakan oleh pemerintah pada jumlah yang cukup dan dengan harga yang dapat dijangkau oleh masyarakat.Produksi gula dalam negeri saat ini tidak sampai 3 juta ton per tahun dan produksi gula tiap tahunnya tidak mengalami pertumbuhan yang berarti, sehingga membuat pemerintah terus melakukan impor gula tidak kurang dari 2,2 juta ton (Kementerian Pertanian, 2012).

Pada tahun 2013 luas area tanaman tebu di Indonesia mencapai 469.227 ha, yang diantaranya terdapat di Pulau Tebu sebesar 303.363 ha, Sumatra sebesar 147.325 ha dan Sulawesi 18.539 ha (BPS Perkebunan Indonesia, 2013). Dengan potensi luah lahan tanaman tebu yang cukup besar, produksi gula nasional ternyata belum mampu mengatasi permintaan akan gula. Untuk mencukupi konsumsi gula nasional, Indonesia menjadi importir gula.

Kabupaten Kediri memiliki potensi produksi komoditi perkebunan tebu yang cukup baik, jika dibandingkan dengan tanaman perkebunan lain yang ada di Kabupaten Kediri, tanaman tebu mampu memproduksi dengan hasil yang cukup tinggi. Sentra produksi tebu di Kabupaten Kediri berada di Kecamatan Kandat, Ngadiluwih, dan Wates. Budidaya tanaman ini telah dikenal dengan baik hampir oleh seluruh masyarakat, terutama petani lahan kering, namun dalam dua tahun terakhir produksi tebu cenderung mengalami penurunan. Penurunan ini diperkirakan karena banyak petani tebu yang lebih memilih untuk menanam tanaman palawija daripada tebu.

Produksi Unggulan Subsektor perkebunan Tahun 2013-2015 (ton)

\begin{tabular}{|l|l|l|l|}
\hline Tanaman & 2013 & 2014 & 2015 \\
\hline Tebu & 2.619 & 2.453 & 2.338 \\
\hline Kopi & 57 & 56 & 51 \\
\hline Coklat & 359 & 391 & 388 \\
\hline cengkeh & 246 & 276 & 276 \\
\hline
\end{tabular}

Sumber : Kabupaten Kediri Dalam Angka 2016 
Mitra dalam program pengabdian masyarakat ini merupakan usaha mikro Gula Merah Tebu atau yang biasa disebut Gula Merah Tebu yang berasal dari tebu. Usaha mikro Gula Merah Tebu ini terletak di Desa Mangunrejo Kecamatan Ngadiluwih dan Desa Cendono Kecamatan Kandat Kabupaten Kediri.

Proses produksi kedua mitra memang sudah menggunakan mesin, namun hanya untuk menggiling tebu untuk diambil sarinya, sedangkan proses lainnya masih manual menggunakan alat yang sederhana mulai dari merebus sari tebu hingga pencetakan Gula Merah Tebu dan pengoperasian alat-alat tersebut harus dikerjakan oleh tenaga kerja manusia. Dari hasil produksi saat ini Gula Merah Tebu yang dihasilkan tiap harinya ratarata mencapai 1 ton Gula Merah Tebu dengan bahan baku sebanyak 10 hingga 13 ton tebu yang akan digiling. biaya produksi yang harus dikeluarkan kedua mitra tiap 1 ton Gula Merah Tebu adalah sekitar 3 juta, biaya ini termasuk untuk tebang angkut, operasional penggilingan, dan upah tenaga kerja.

\section{ANALISIS KONDISI}

\section{a. Produk Gula Merah Tebu}

Kedua mitra merupakan pabrik rumahan Gula Merah Tebu yang bertempat tinggal di Desa Mangunrejo Kecamatan Ngadiluwih dan Desa Cendono Kabupaten Kandat Kabupaten Kediri. Pembuatan Gula Merah Tebu yang dilakukan kedua mitra masih menggunakan peralatan yang sederhana, kebanyakan prosesnya masih menggunakan tenaga manusia, hanya untuk memeras air tebu yang menggunakan mesin yang digerakkan oleh diesel dan dinamo. Dalam pembuatan Gula Merah Tebu tidak jauh beda dengan pembuatan Gula Merah pada umumnya, namun terdapat sedikit perbedaan dalam penggunaan bahan dasar. Gula Merah biasanya menggunakan air nira sebagai bahan dasar sedangkan kedua mitra ini menggunakan tebu sebagai bahan dasarnya.

Proses pembuatan Gula Merah Tebu adalah sebagai berikut:

1. Pertama tebu diperas dengan menggunakan mesin penggiling tebu bertenaga dinamo atau diesel

2. Setelah tebu diperas dan diambil airnya tahap selanjutnya adalah air perasan tebu akan direbus di tungku yang sudah ada 
3. Air rebusan tersebut sesekali akan terus diaduk dan akan dipindahkan ke tungku yang lain jika warna air rebusan tebu tersebut mulai berwarna coklat tua

4. Jika warna air rebusan tebu sudah berubah warna dan sedikit mengental, tahap selanjutnya adalah dipindahkan ke wadah besar

5. Di dalam wadah tersebut air gula yang mulai mengental akan diaduk hingga air tebu yang telah benar-benar mengental dan siap untuk dicetak

6. Gula akan ditunggu agak kering dan siap untuk dicetak pada batok kelapa, untuk gula merah tebu pasir, gula akan diaduk terus menerus.

7. Gula yang sudah kering di cetakan batok kelapa akan dilepas

8. Setelah Gula Merah Tebu benar-benar siap untuk dikemas, pengemasan Gula Merah Tebu ini juga masih sangat sederhana hanya menggunakan plastik.

\section{b. Pemasaran}

Gula Merah Tebu yang telah dikemas tiap bal yang berisi seberat $10 \mathrm{~kg}$ akan diambil pengepul Gula Merah Tebu, dimana pengepul Gula Merah Tebu ini akan secara rutin membeli Gula Merah Tebu dari pabrik-pabrik Gula Merah Tebu setiap hari. Dari para pengepul ini pendapatan pabrik Gula Merah Tebu diperoleh dengan harga jual tiap kg Gula Merah Tebu sekitar 10.000 hingga 11.000.

\section{c. Pola Manajemen}

Proses produksi kedua mitra memang sudah menggunakan mesin, namun hanya untuk menggiling tebu untuk diambil sarinya, sedangkan proses lainnya masih manual menggunakan alat yang sederhana mulai dari merebus sari tebu hingga pencetakan Gula Merah Tebu dan pengoperasian alat-alat tersebut harus dikerjakan oleh tenaga kerja manusia. Dari hasil produksi saat ini Gula Merah Tebu yang dihasilkan tiap harinya ratarata mencapai 1 ton Gula Merah Tebu dengan bahan baku sebanyak 10 hingga 13 ton tebu yang akan digiling. biaya produksi yang harus dikeluarkan kedua mitra tiap 1 ton Gula Merah Tebu adalah sekitar 3 juta, biaya ini termasuk untuk tebang angkut, operasional penggilingan, dan upah tenaga kerja. 


\section{PERMASALAHAN}

Kegiatan survei yang telah dilakukan di kedua mitra Pengabdian Kepada Masyarakat menemukan beberapa permasalahan yaitu:

1. Tempat penyimpanan sisa tebu yang digiling perlu diperluas

2. Penjualan produk Gula Merah Tebu tergantung dari pengepul

3. Pencatatan laporan keuangan, hasil produksi dan penjualan belum ada

4. Beberapa alat untuk proses produksi masih menggunakan alat yang manual yang dikerjakan oleh tenaga manusia

\section{METODE PELAKSANAAN}

Untuk mengatasi permasalah yang terjadi di mitra dalam mengembangkan produk usaha maka dari peneliti melakukan beberapa hal untuk mencoba memberikan alternatif untuk penyelesaian masalah. Langkah - langkah yang dilakukan adalah: (a). Tim peneliti melakukan pertemuan dengan kedua mitra untuk memetakan permasalahan dan mengetahui kondisi produksi gula merah tebu yang telah diproduksi oleh kedua mitra. (b). Memberikan pelatihan pemasaran produk kepada kedua mitra. (c). Memberikan pelatihan pembukuan laporan keuangan untuk memisah harta usaha dan harta pribadi. (d) memberikan bantuan dinamo listrik dan mesin pengkristal gula (e). Serta memberikan bantuan untuk pembenahan gudang penyimpanan sisa gilingan tebu yang dapat digunakan untuk bahan bakar memasak air gula tebu.

Gambaran proses yang dilakukan di kedua mitra adalah sebagai berikut:

Gambar 1. Diagram proses kegiatan PKM

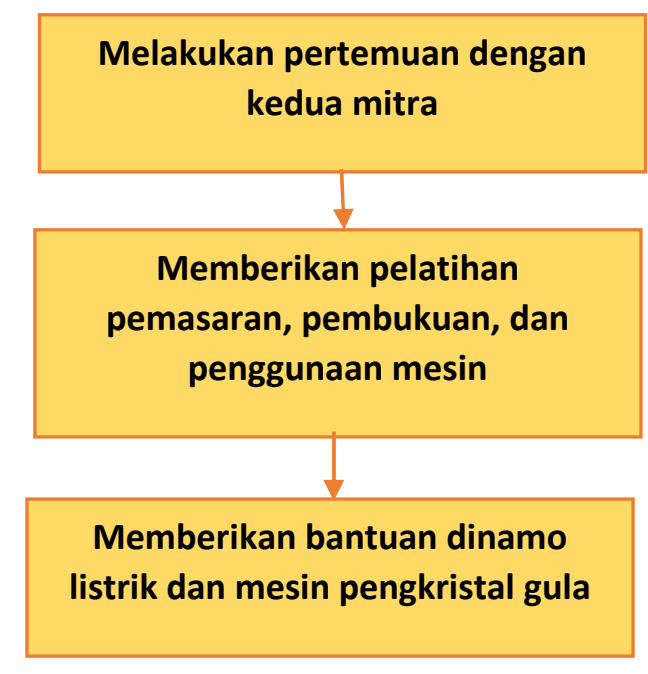




\section{a. Pelatihan Pemasaran}

Pelatihan pemasaran perlu dilakukan karena melihat selama ini kedua mitra belum mampu menjual produk gula jawa merah sendiri dan dengan merek produk mereka sendiri. Selama ini mereka menjual produk gula jawa merah melalui pengepul yang mengambil produk mereka per hari. Pelatihan ini lebih menekankan pada pentingnya memiliki merek produk sendiri serta pengepakan produk agar dapat dibeli konsumen rumah tangga.

\section{b. Pelatihan Pembukuan Keuangan}

Kedua mitra kegiatan PKM selama menjalankan usaha pembuatan gula merah tebu belum pernah melakukan pencatatan laporan keuangan perusahaan. Selama ini kedua mitra menjalankan usaha hanya karena kebiasaan yang dilakukan tiap hari, semua transaksi dilakukan karena sudah hafal sehingga kedua mitra menganggap belum butuh melakukan pencatatan laporan keuangan. Pelatihan pembukuan ini penting untuk kedua mitra karena dengan melakukan pencatatan laporan keuangan kedua mitra mampu membedakan mana harta perusahaan dan harta milik pemilik, selain itu pemilik juga dapat mengetahui berapa aset perusahaan dan perkembangan perusahaan. Dengan memiliki laporan keuangan perusahaan, kedua mitra memiliki syarat untuk melakukan peminjaman modal di lembaga keuangan.

\section{c. Pelatihan Penggunaan Mesin Pengkristal Gula}

Salah satu kegiatan PKM yang dilakukan kapada kedua mitra adalah pemberian bantuan mesin pengkristal gula, dimana mesin ini mampu menghasilkan deferensiasi produk dari gula merah tebu. Produk yang biasanya diproduksi oleh kedua mitra adalah gula bathok, sedangkan dengan mesin ini produk yang dihasilkan adalah gula bubuk atau biasa masyarakat menyebut gula garuk.

Proses yang dilakukan dalam pelatihan penggunaan mesin pengkristal gula ini hampir sama dengan pembuatan gula bathok namun yang berbeda adalah ketika dimasak dan gula matang, air gula tersebut dipindahkan ke mesin pengkristal gula dan selanjutnya oleh mesin ini akan diaduk sampai gula tersebut kering dan berbentuk gula garuk. 


\section{HASIL DAN PEMBAHASAN}

Hasil yang telah dicapai dalam kegiatan pengabdian masyarakat yang diadakan di Desa Mangunrejo dan Desa Cendono Kabupaten Kediri adalah sebagai berikut:

\section{a. Bagian Operasional}

1. Perbaikan tempat penyimpanan limbah tebu yang akan digunakan sebagai bahan bakar memasak gula

Kondisi tempat penyimpanan ketika survei

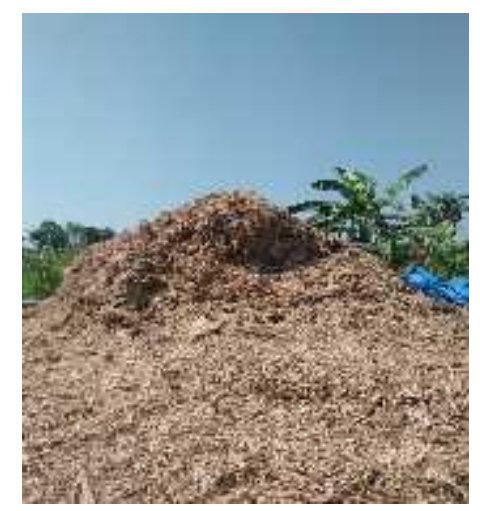

Gambar 2. Limbah Sisa penggilingan tebu

Ketika melakukan survei kondisi gudang penyimpanan tidak mencukupi sehingga sisa penggilingan tebu harus ditaruh di luar tempat produksi dan hanya ditutup dengan plastik terpal. Setelah dilakukan kegiatan pengabdian kepada masyarakat, mitra dibantu sejumlah dana untuk membangun gudang penyimpanan sisa penggilingan tebu yang baru dengan kapasitas yang lebih besar.

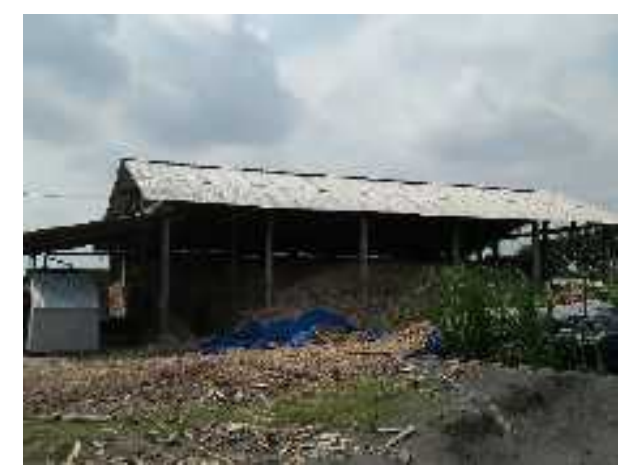

Gambar 3. Gudang penyimpanan baru 


\section{Penambahan tenaga dinamo untuk pemutar penggiling tebu dan sebagai alat crane}

untuk mengangkat tebu dari truck

Sejak pertama memulai usaha gula tebu merah, mitra masih menggunakan diesel sebagai tenaga untuk memutar mesin penggiling, selama kegiatan pengabdian masyarakat mitra merasa dengan menggunakan diesel berbahan bakar solar pengeluaran akan semakin besar karena harga solar yang semakin mahal.

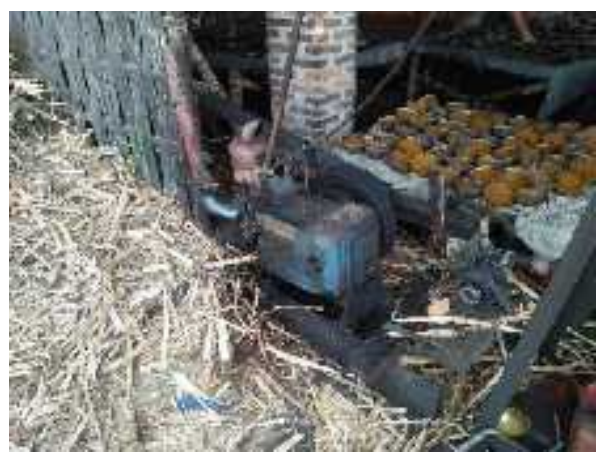

Gambar 4. Diesel untuk memutar mesin penggiling

Ada dua bantuan yang diberikat terkait dengan dinamo listrik ini, penggunaan dinamo listrik oleh kedua mitra digunakan untuk kebutuhan yang berbeda. Mitra pertama menggunakan dinamo listrik untuk menambah kapasitas produksi dengan menggantin diesel menjadi dinamo listrik untuk memutar mesin penggiling. Sedangkan mitra kedua akan membangun crane umtuk mengangkat tebu dari truk, dinamo litrik di mitra kedua digunakan untuk tenaga penggerak crane ini.

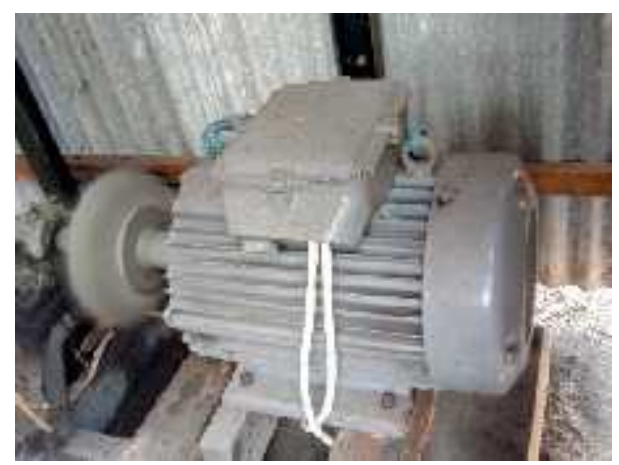

Gambar 5. Dinamo penggerak mesin penggiling 


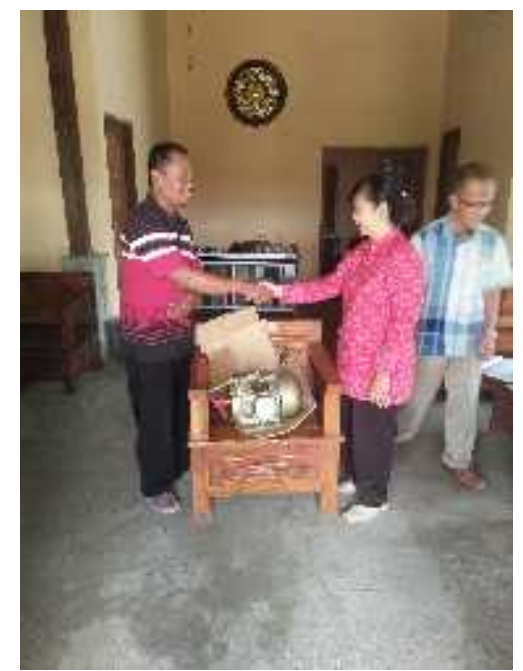

Gambar 6. Dinamo untuk crane

\section{Tenaga kerja dapat dioptimalkan}

Sebelum menggunakan dinamo tenaga kerja mampu menghasilkan gula merah tebu sebanyak 500 kwintal, sedangkan sekarang setelah mendapat dinamo untuk menggiling tebu dan crane tenaga kerja mampu menghasilkan 1 ton gula merah tebu.

Kedua mitra selama ini menggunakan tenaga kerja sebanyak 7 orang yang dibagi ke berbagai tugas. 2 orang hanya pada bagian pengilingan tebu dan pengangkatan sisa penggilingan tebu untuk dibawa ke gudang penyimpanan sisa penggilingan tebu. 1 orang ditempatkan pada bagian pemasakan atau pembakaran tungku masak air gula tebu. untuk 4 oran sisanya akan secara bergantian bagian cek air gula tebu yang dimasak sudah matang dan bagian mencetak gula tebu ke dalam batok kelapa.

Selama ini tenaga kerja di bayar harian, tiap 1 kwintal gula merah yang siap dikemas para pekerja mendapat Rp 50.000. ini dianggap wajar oleh pemilik usaha gula merah, namun yang menjadi ancaman adalah sewaktu - waktu pekerja dapat meninggalkan pekerjaan karena berbagai hal.

Ketika ada satu pekerja yang tidak masuk adan menjadi masalah dalam produksi karena pencapaian gula merah tebu yang dihasilkan juga berkurang. Untuk mengatasi hal tersebut biasanya pemilik perusahaan akan menambah jam kerja hingga malam, dan itu akan menambah biaya produksi bagi pemilik perusahaan karena harus menyediakan makan dan upah tambahan. 
Saat kegiatan pengabdian kepada masyarakat ini kedua mitra disarankan untuk mengikat seluruh pekerjanya dengan mengupah tenaga kerjanya tiap bulan sehingga kekhawatiran tiba-tiba ada pekerja yang keluar dari pekerjaan dapat diminimalkan, karena ketika ada pekerja yang keluar, pemilik usaha kesulitan untuk mencari tenaga kerja yang mau bekerja di pabrik pembuatan gula merah tebu rumahan. Kebanyakan mereka memilih bekerja di pabrik yang lebih besar.

\section{Penggunaan crane}

Adanya crane di salah satu mitra memudahkan pemindahan tebu dari truk ke penggilingan. jadi tidak menggunakan tenaga manusia lagi, sehingga tenaga kerja dapat dimaksimalkan pada proses produksi gula tebu merah.

Dengan adanya crane ini dapat memangkas waktu dalam pengangkatan tebu dari truk, karena sebelum menggunakan crane ini ketika harus bongkar tebu dari truk semua pekerja menghentikan pekerjaannya dan beralih mengangkat tebu terlebih dahulu. Waktu yang dibutuhkan bongkar tebu dari truk biasanya antara 15 sampai 30 menit, jadi selama itu juga proses produksi sedikit terhambat.

Kegiatan pengabdian masyarakat di kedua mitra dibantu penyediaan dinamo motor listrik untuk menggerakkan crane tersebut. Cara kerja crane ini adalah tebu dari truk diangkat oleh crane dalam satu ikatan lalu dari crane dipindahkan ke area penggilingan. Dengan menggunakan crane ini hanya membutuhkan 1 orang untuk mengoperasikannya, ini menunjukkan bahwa ketika tebu baru tiba di pabrik pekerja yang lain sudah tidak perlu meninggalkan pekerjaan hanya untuk bongkar tebu tersebut. 


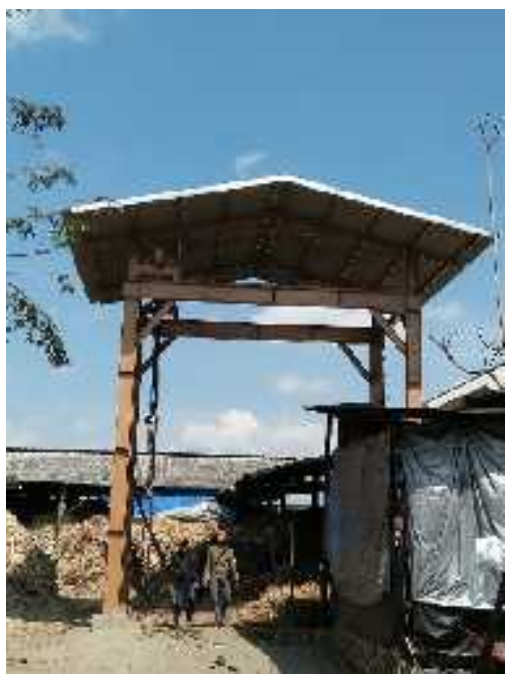

Gambar 7. Crane yang digunakan untuk memindah tebu dari truk

\section{Mesin pengkristal gula}

Sejak pertama berdiri kedua mitra memproduksi gula merah tebu yang berbentuk batok dan itu masih tetap berjalan sampai hari ini. Selama ini juga alat untuk penampung gula yang sudah matang masih menggunakan alat yang sederhana terbuat dari kayu nangka.

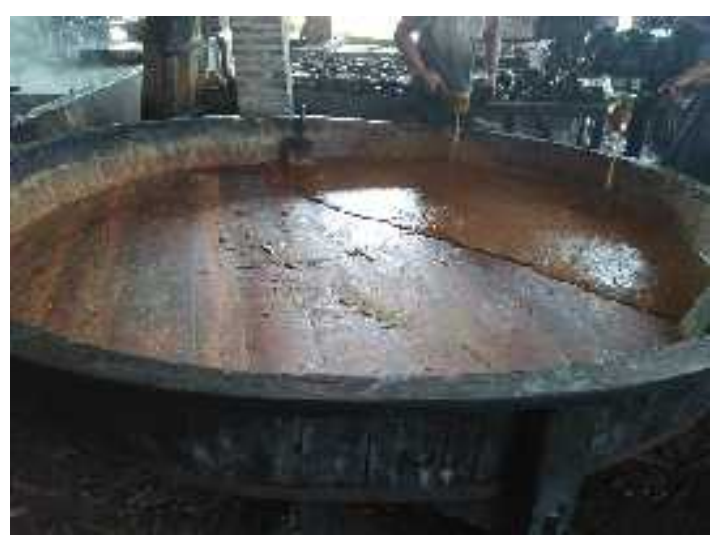

gambar 8. Alat penampung gula yang sudah matang

Proses pembuatannya selama ini masih manual, alat pencetaknya juga masih dari batok kelapa. Hasil dari pencetakan gula yang sudah kering akan dikemas tiap 10 kilogram di dalam plastik besar. Selanjutnya kemasan-kemasan tersebut akan diambil oleh pengepul. 
Mitra kegiatan pengabdian masyarakat dicoba untuk melakukan diferensiasi produk yaitu selain memproduksi gula merah tebu batok, juga memproduksi gula semut (gula garuk). Gula garuk biasanya digunakan untuk kebutuhan rumah tangga, sehingga dengan mitra mampu membuat gula semut (gula garuk) ketergantungan dengan pengepul dapat dikurangi karena dengan memproduksi gula semut (gula garuk) kemasan dapat lebih dijangkau oleh masyarakat. Kemasan yang lebih kecil dibandingkan dengan gula merah batok, membuat gula garuk memiliki potensi untuk dijual secara lebih luas.

Mesin pengkristal gula yang diberikan kepada mitra didatangkan dari Yogyakarta, mesin ini mampu menghasilkan gula semut sampai 20 kilogram sekali proses.

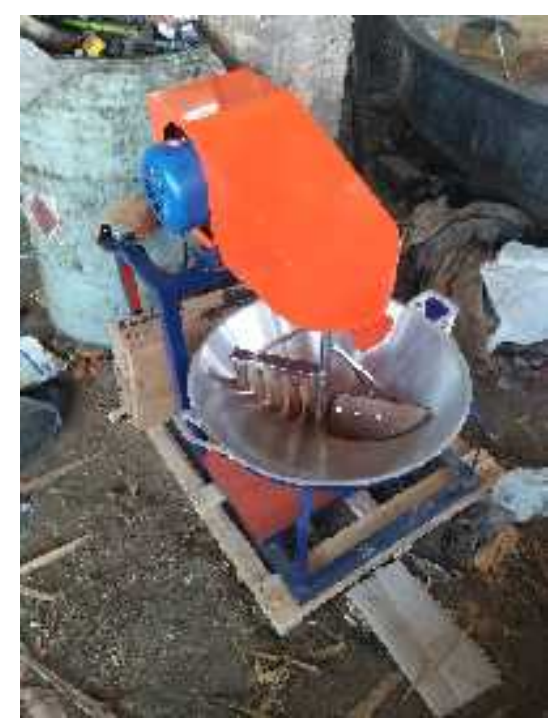

Gambar 9. Mesin pengkristal gula

Kapasitas mesin ini masih kecil untuk melakukan produksi dalam jumlah besar, namun untuk memulai produk baru dengan mesin ini dapat digunakan untuk uji coba kemasan gula semut yang dikonsumsi oleh rumah tangga. 


\section{b. Bagian Manajemen}

\section{Adanya perbaikan pembukuan transaksi keuangan dan pelatihan pemasaran}

produk

Sebelumnya pencataan keuangan tidak pernah dibukukan hanya catatancatatan kecil yang dikumpulkan. Pemilik usaha menjalankan usaha atas dasar kebiasaan saja, jadi berapa biaya dan keuntungan yang diperoleh juga atas dasar kebiasaan yang diperoleh setiap hari.

Pemilik usaha tidak memiliki buku pencatatan perputaran kas setiap hari. Hal ini menyebabkan pemilik tidak membedakan harta perusahaan dan harta pribadi, anggapan pemilik usaha keuntungan yang diperoleh perusahaan merupakan keuntungan pribadi dan kerugian maupun biaya yang ditanggung perusahaan merupakan tanggung jawab pribadi. Terkadang pemilik usaha sampai mengeluarkan harta sendiri untuk membayar tenaga kerja dan pemilik perusahaan tidak dihitung upah yang diperoleh dari hasil produksi hari itu.

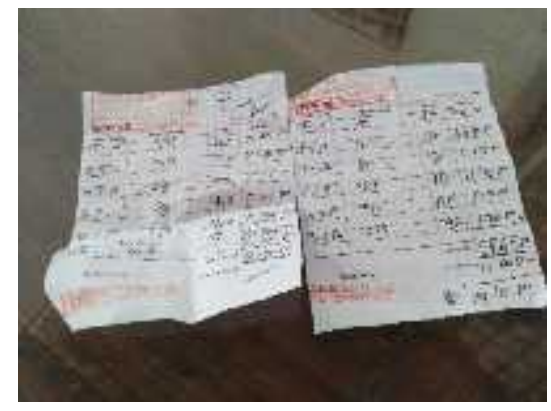

Gambar 10. Catatan transaksi jual beli tebu dan gula

Pelatihan pencatatan laporan keuangan dirasa perlu dalam kegiatan pengabdian masyarakat ini karena dengan memiliki laporan keuangan pemilik dapat memprediksi perkembangan usahanya, serta ketika pemilik membutuhkan tambahan modal, laporan keuangan yang dimiliki dapat dijadikan bukti bahwa usaha produksi gula merah tebu ini memiliki prospek untuk terus berkembang. 


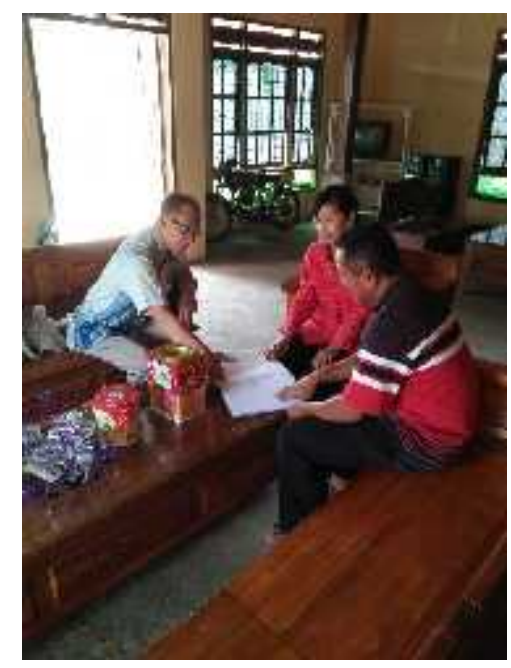

Gambar 11. Kegiatan pelatihan pencatatan laporan keuangan dan pemasaran

\section{Penggunaan merk logo produk}

Proses pemasaran produk gula merah tebu ini diambil oleh pengepul sehingga tidak memungkinkan untuk membuat merk produk karena oleh pengepul merk tersebut akan dibuang. Oleh karena kegiatan pengabdian ini diusahakan pemilik usaha memiliki produk baru serta pengemasan yang baru, sehingga dibutuhkan merek produk untuk produk tersebut.

Proses pendaftaran merek produk hanya sampai pembayaran pendaftaran merek produk karena untuk sah memiliki harus menunggu persetujuan dari Kemenkumham. Jadi untuk menunggu merek produk di sahkan maka uji coba pembuatan gula semut yang dapat dikonsumsi masyarakat akan terus dilakukan.

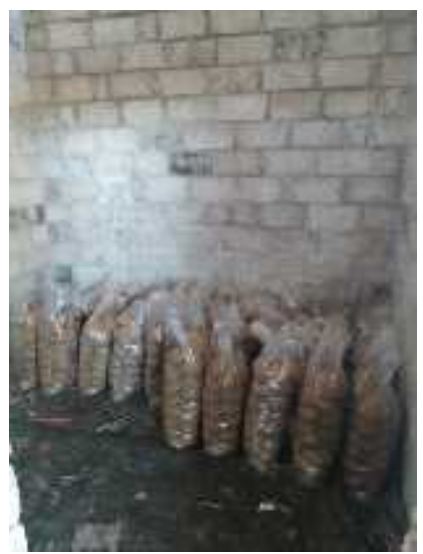

Gambar 12. Produk yang belum memiliki merek produk 


\section{KESIMPULAN}

Kesimpulan yang diperoleh dari kegiatan pengabdian ini adalah:

1. Adanya kegiatan pengabdian masyarakat ini membantu mitra untuk menyempurnakan sistem manajemen perusahaan yang dimiliki, karena sejak pertama berdirinya usaha pembuatan gula merah ini belum ada sistem manajemen perusahaan yang baik, selama ini operasional perusahaan dijalankan karena kebiasaan saja.

2. Gula merah tebu memiliki potensi harga dan pasar yang luas karena produk ini banyak yang membutuhkan mulai dari rumah tangga hingga industri kecap, bahkan pasar luar negeri pun siap menampung produk gula merah tebu ini.

3. Mitra kegiatan pengabdian ini dicoba untuk dilakukan diferensiasi produk, yaitu dengan menghasilkan produk gula semut, dimana gula semut ini dapat dikemas per kilogram dan dapat dijual langsung di pasar kepada konsumen akhir.

4. Ada beberapa pelatihan yang dirasa perlu dilakukan yaitu pelatihan pemasaran produk, karena selama ini mitra belum mampu menjual produknya sendiri masih tergantung dengan pengepul

5. Pelatihan pembukuan laporan keuangan, ini dikarenakan pemilik usaha tidak pernah mencatan semua transaksi dan hasil produksi hari itu.

\section{Daftar Pustaka}

Badan Pusat Statistik. 2013. Produksi Perkebunan Menurut Provinsi dan Jenis Tanaman. Badan Pusat Statistik

Badan Pusat Statistik. 2016. Kabupaten Kediri Dalam Angka 2016. Kabupaten Kediri. BPS Kabupaten Kediri

Direktorat Jenderal Perkebunan. 2012. Rencana Strategis Pembangunan Perkebunan 2010-2014, Kementerian Pertanian RI.

Ginandjar, G. R. (2012). Kebijakan industri gula rafinasi dalam pembangunan industri gula nasional. Dalam Bayu Krisnamurthi (Ed.). Ekonomi gula (hal. 271-286). Jakarta: PT Gramedia

Koo, W. W. and Taylor, R. D. (2011). Outlook of the US and world sugar markets, 20102020. US Agricultural Economics Report No. 444, July 2000. North Dakota State 
University. Diperoleh tanggal 20 Mei 2016, dari http://ageconsearch.umn.edu/bitstream/23148/1/aer444.pdf

http://choirinakdr.blogspot.co.id/2013/02/makalah-tentang-desaku.html, diakses pada tanggal 20 Mei 2016 
